\title{
The Anglo-Saxon Chapel of St Helen at Malmesbury
}

\author{
Michael Hare
}

Many years ago, Barbara Yorke mentioned to me that an Anglo-Saxon church, known as St Helen's, had recently been discovered during alterations to a house at Malmesbury. During a subsequent visit to Malmesbury I failed to find the building in question! However, serendipity then intervened when I encountered the present owners, Kes and Mary Smith, at Deerhurst and discovered that, having acquired an Anglo-Saxon church, they had developed an interest in Anglo-Saxon church architecture. They invited me to visit and have subsequently encouraged me to study the building.

\section{The Site of St Helen's}

The town of Malmesbury occupies a steep-sided irregular limestone promontory. ${ }^{1}$ The town is largely surrounded by two rivers which meet at the southeast corner, the Sherston branch of the (Bristol) Avon on the south and west and the Tetbury branch of the Avon to the east and north (Fig. 21.1). It has long been proposed that Malmesbury had its origins in a bivallate Iron Age hillfort, and this has recently been established by excavations on the eastern side of the town. ${ }^{2}$ A monastery was established at Malmesbury in the 7 th century and occupied the north-western corner of the hillfort. St Aldhelm, a member of the West Saxon royal house, became abbot $c .680$ or a little later. ${ }^{3}$ Malmesbury is listed in the Burghal Hidage of late 9th- or early 1oth-century date, ${ }^{4}$ and it

1 For a contour plan of the town at 2 m intervals, see Jeremy Haslam, "The Towns of Wiltshire," in Anglo-Saxon Towns in Southern England, ed. Jeremy Haslam (Chichester, 1984), pp. 87-147, Fig. 48 (at p. 116).

2 Timothy Longman, "Iron Age and Later Defences at Malmesbury: Excavations 1998-200o," WANHM 99 (2006), 105-64; Mark Collard and Tim Havard, "The Prehistoric and Medieval Defences of Malmesbury: Archaeological Investigations at Holloway, 2005-2006," WANHM 104 (2011), 79-94.

3 The early history of the abbey is summarized by S.E. Kelly, ed., Charters of Malmesbury Abbey, Anglo-Saxon Charters 11 (Oxford, 2005), pp. 1-34; for the date of Aldhelm's appointment as abbot, see Michael Lapidge, "The Career of Aldhelm," ASE 36 (2007), 15-69, at 48-52.

4 Alexander R. Rumble, "An Edition and Translation of the Burghal Hidage, together with Recension C of the Tribal Hidage," in The Defence of Wessex: The Burghal Hidage and Anglo-Saxon Fortifications, ed. David Hill and Alexander R. Rumble (Manchester, 1996), pp. 14-35, at 26-27 


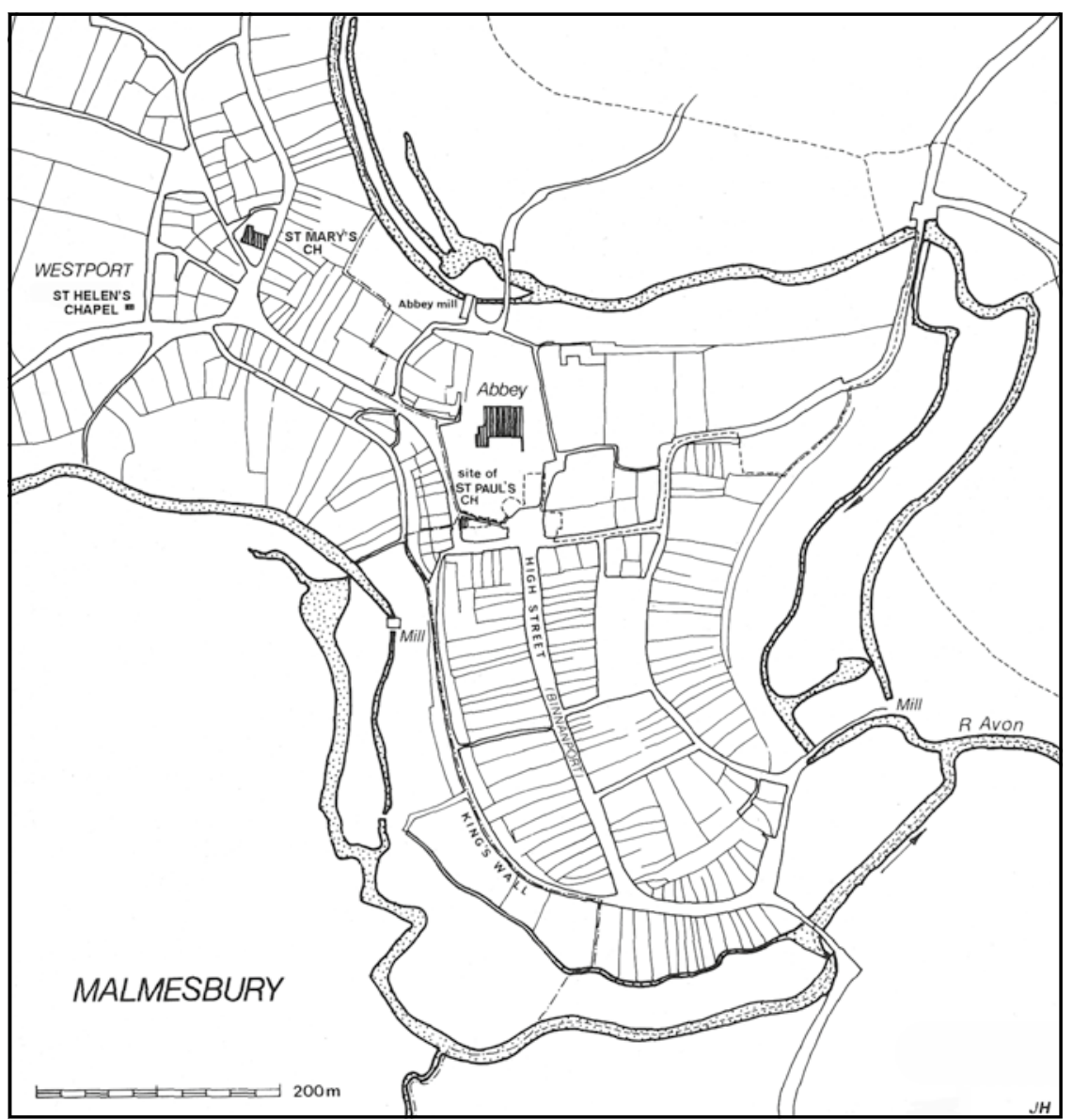

FIGURE 21.1 Map to show the position of the former chapel of St Helen at Malmesbury in the suburb of Westport

ADAPTED BY RICHARD BRYANT FROM AN ORIGINAL MAP BY JEREMY HASLAM

seems very probable that the defences of the Iron Age hillfort were adapted when the burh was created. At one point a substantial earth and stone bank of 10th- or 11th-century date has been identified on the line of the inner Iron Age defences. ${ }^{5}$

(text), 33 (translation). See also Barbara Yorke, Wessex in the Early Middle Ages (London, 1995), pp. $115^{-21 .}$

5 Longman, "Iron Age and Later Defences," pp. 125-30, 160-61. For a general discussion of the town in the early medieval period, see Haslam, "The Towns of Wiltshire," pp. 111-17. 
At the north-west corner of Malmesbury a narrow neck of high ground connects the town with a broader area of high ground to the west between the two rivers. ${ }^{6}$ This area was outside Malmesbury's Iron Age hillfort, and a medieval suburb known as Westport occupied the neck of land and the area immediately to its west. A major road (Bristol Street) runs through the suburb parallel to the Sherston Avon to the south. St Helen's is located on the north side of this street at Nat. Grid Ref ST 9297787406 , about $250 \mathrm{~m}$ from the former west gate of the town; the south wall of the house is set back about $10.60 \mathrm{~m}$ from the modern street frontage. The building stands on a south-facing slope about $1.75 \mathrm{~m}$ above street level; the ground continues to rise to the rear of the house.

\section{The discovery of St Helen's}

It was long believed that the house called St Helen's stood on the site of a chapel dedicated to St Helen. For instance in 1805 the Rev'd J.M. Moffatt in his History of the Town of Malmesbury wrote that:

At the corner of a street, formerly called Milk-Street, near the road to Sherston, stands a house which is denominated St. Hellen's, on the same spot where formerly stood St. Hellen's Chapel. In the wall of the garden belonging to this house, is fixed a calvary cross. ${ }^{7}$

It was therefore something of a surprise when redevelopment of the area revealed that the walls of the chapel were preserved in the house.

In the years after World War Two there was considerable pressure to remove poor quality housing, to build new houses and to provide wider roads. In 1967 the Borough Council obtained outline planning permission to redevelop the area to the west of West Street (the north-south street a little to the east of St Helen's); this redevelopment would have involved the demolition of St Helen's. Fortunately Malmesbury Civic Trust made an appeal for renovation of the area rather than demolition. ${ }^{8}$ In $1976-79$ a private initiative took place which involved the refurbishment of a number of houses at the southern end of West

$6 \quad$ Leland put it neatly, "Newton water and Avon ren so nere togither in the botom of the west suburbe at Malmesbyri, that there within a burbolt-shot the toun is peninsulatid": Lucy Toulmin Smith, ed., The Itinerary of John Leland in or about the years 1535-1543, 5 vols. (London, 1906-10), 1:131.

7 J.M. Moffatt, The History of the Town of Malmesbury, and of its Ancient Abbey (Tetbury, 1805), pp. 102-03.

8 Charles Vernon, Malmesbury's Past, People and Places (Malmesbury, 2014), p. 64. 
Street together with St Helen's and the cottages to its west. It was in the course of this work that the early medieval fabric came to light when pebbledash and whitewash was removed from the walls; the building was recognized in 1980 as a church of Anglo-Saxon date by the late John Bowen of Malmesbury. ${ }^{9}$

A photograph taken during the work, showing the house from the north, indicates that it was completely gutted. ${ }^{10}$ Unfortunately no archaeological observation took place during the work, and much more could doubtless have been learnt at that time. There are no reports of burials having been seen during the work.

Since the discovery, there have been many brief references in print to St Helen's, but the building has not yet received a detailed study. ${ }^{11}$

\section{Description}

The present house consists of the nave of the church, but it will be suggested below that there was formerly a narrower chancel to its east. The house (23 Bristol Street) now forms the eastern end of a terrace, the remaining houses (Nos 25, 27, and 29) being of 19th-century origin; early maps show that there was also a narrow structure adjoining St Helen's at the east end of the terrace. ${ }^{12}$ The nave is clearly defined by megalithic quoins (discussed in more detail below) at the south-west, south-east, and north-east angles. Internally it is divided into two floors, with a further room above in an attic space. To the rear there is a flat-roofed two-storeyed extension of modern date. The west wall of St Helen's is obscured by the 19th-century house to the west, and no details of its construction are visible. The north wall is now an internal wall within the house, again with no constructional details visible. The photograph of the house from the north taken during the refurbishment of the house in the 1970s

9 John Bowen, The Story of Malmesbury: part one, 50o BC-160o AD (Malmesbury, 200o), pp. 31-32. The information that the building was pebbledashed comes from a former 'listed building' description, available in the Historic England Archive, file BFo83999; the remains of whitewash are still visible in places.

10 I am grateful to Kes and Mary Smith for showing me this photograph.

11 There is an unpublished description dated 1992 by the Royal Commission on Historical Monuments (England) [hereafter RCHME], now available in the Historic England Archive, file BFo83999. Warwick Rodwell has drawn attention to the building on more than one occasion; see for instance Warwick Rodwell, The Archaeology of Churches (Stroud, 2012), pp. 41, 196.

12 This structure appears on a map of 1845 (Wiltshire and Swindon Archives 815/27L), which also shows that the adjoining cottages to the west had been built by that date. St Helen's is listed Grade II ${ }^{*}$, and Nos $25^{-29}$ Grade II; No. 29 is set forward closer to the street. 


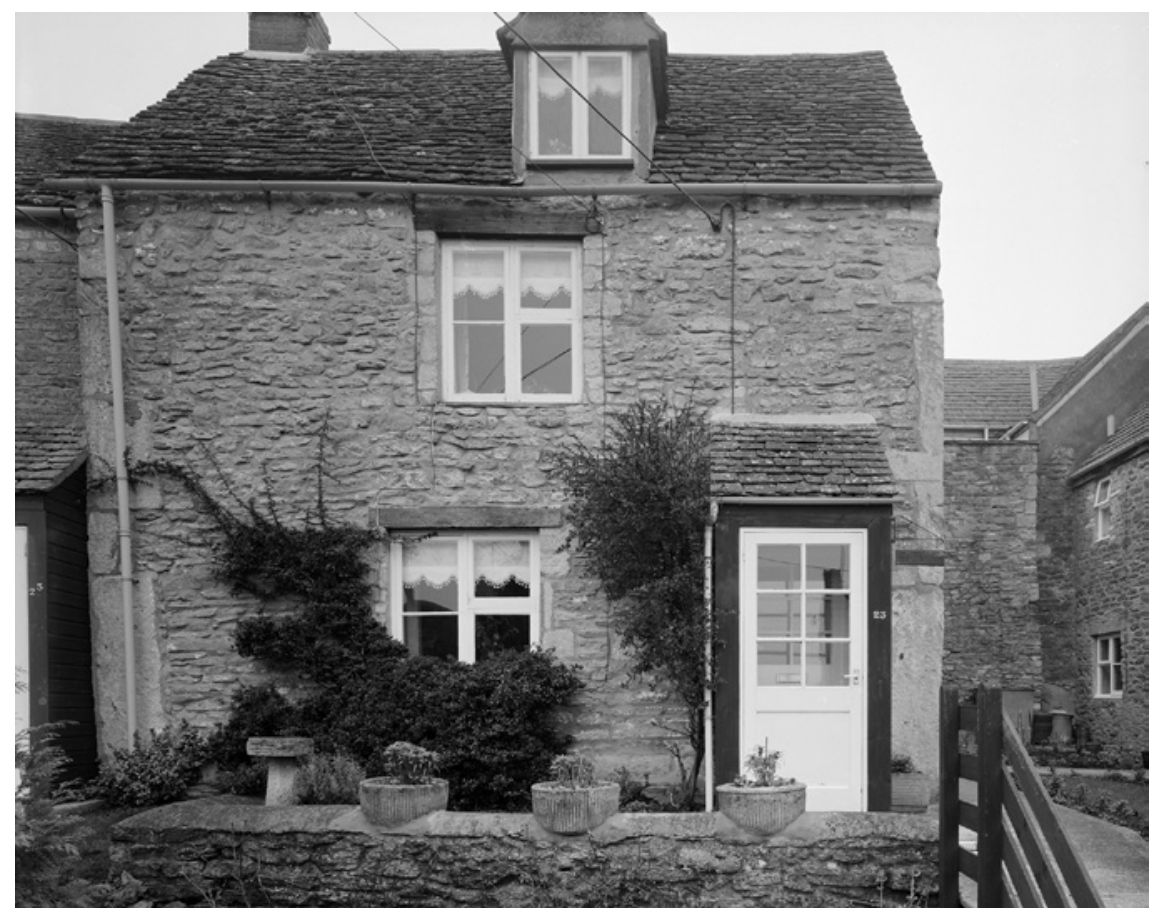

FIGURE 21.2 View of the south wall of the former chapel of St Helen at Malmesbury in 1992 (C) CROWN COPYRIGHT. HISTORIC ENGLAND ARCHIVE (REF. BB/15932).

shows the stubs of stone walls projecting northwards from the north-east and north-west corners, suggesting that there was an earlier structure on the site of the modern extension. It may well be that the north-west quoin also survives, but it is completely encased by later structures.

The nave measures externally $6.82 \mathrm{~m}$ in length and $4.40 \mathrm{~m}$ in width; internally the nave, as far as can be measured, is $5.64 \mathrm{~m}$ in length and $3.24 \mathrm{~m}$ in width. The walls are thin, measuring between $0.5^{8} \mathrm{~m}$ and $0.65 \mathrm{~m}$ in thickness, with a pronounced batter (more noticeable internally than externally). ${ }^{13}$ The south wall (Fig. 21.2) is built of roughly-coursed limestone rubble and it stands on a square plinth of undressed stonework projecting about $0.10 \mathrm{~m}-0.15 \mathrm{~m}$ from the wall face. The wall is $4.66 \mathrm{~m}$ in height above the plinth, but has at some stage been raised by about $0.60 \mathrm{~m}$, probably when the building was converted into a two-storeyed cottage and the present 17 th-century roof was added. There is a doorway with a small modern porch towards the east end and windows

13 At one point the thickness of the north wall is $0.70 \mathrm{~m}$, but the fabric is not certainly ancient here. 


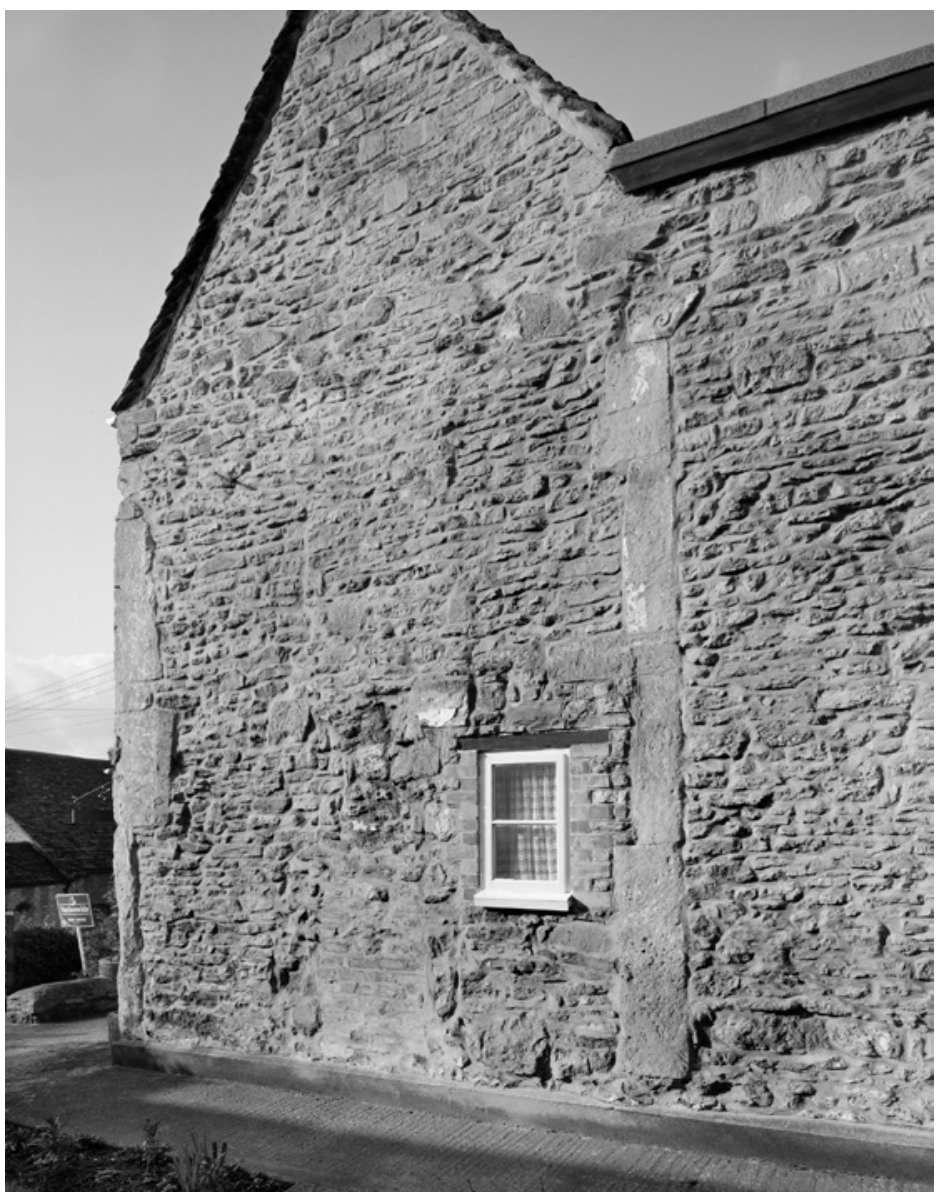

FIGURE 21.3 View of the east wall of the former chapel of St Helen at Malmesbury in 1992 (C) CROWN COPYRIGHT. HISTORIC ENGLAND ARCHIVE (REF. BB/15936).

lighting the ground and upper floors in the centre of the wall, with a dormer window lighting the attic. ${ }^{14}$ There is no clear evidence for early windows or doorways. A disturbed area about $0.60 \mathrm{~m}$ wide between two straight joints above and to the left of the porch has been interpreted as a blocked early window, ${ }^{15}$ this is possible, but the evidence is by no means convincing. It has also been suggested that the ground-floor window formed part of a doorway; ${ }^{16}$

\footnotetext{
14 For a fuller account of the later features of the building, see the listed building description available at <www.britishlistedbuildings.co.uk/en-46o688-23-bristol-street-malmesbury\#.VviTym_2bIU> (accessed 18 Nov. 2017).

15 In the RCHME description quoted in $\mathrm{n}$. 11 above.

16 In the listed building description quoted in n. 14 above.
} 


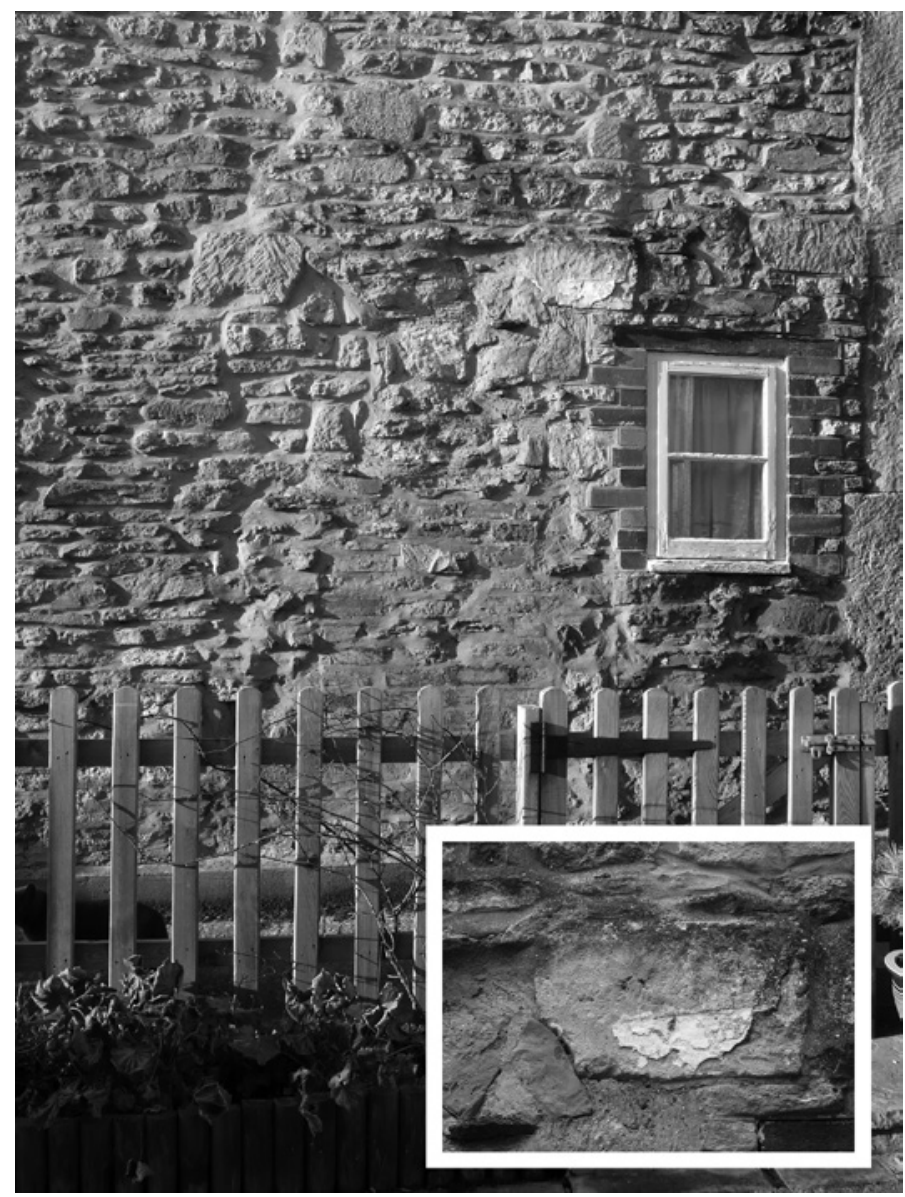

FIGURE 21.4 View showing the remains of the blocked chancel-arch of the former chapel of St Helen at Malmesbury, with (inset) detail of the impost on the north side

(C) AUTHOR

the jamb of the eastern side of the window is formed of larger stones than the western jamb, but there is no sign of an opening beneath the window-sill.

The gabled east wall (Fig. 21.3) now has only a small modern window at ground-floor level, close to the north-east quoin of the nave. However, there is evidence for a former opening towards the centre of the wall, and it is suggested that this opening was originally a chancel-arch. The principal evidence is provided by two large blocks which seem to have been the original imposts of the opening (Fig. 21.4); both imposts display broad hollow chamfers, that on the north side revealed after the removal of a small quantity of mortar. The width 
of the opening, as measured at the base of the imposts, was $0.96 \mathrm{~m}$, and its height to the top of the imposts (above the level of the plinth in the south wall) is $2.37 \mathrm{~m}$; with a round head, the original height would have been in the order of $2.82 \mathrm{~m}$. The head of the opening is lost, though a faint outline in the masonry might indeed suggest the former presence of a round-headed opening. The jambs of the opening are also lost, but the blocking of the opening is clear and includes much brick. The use of brick suggests that the opening may have continued in use after it ceased to function as an arch between nave and chancel; it may perhaps have served as an entry to the building after the chancel was demolished or it may have provided access to the structure to the east visible on 19th-century maps. The opening is not quite central to the wall, being displaced some $0.14 \mathrm{~m}$ to the north; erratic setting out is common in early medieval buildings. Above this opening there is a further disturbed area, perhaps representing a square-headed window of domestic character. ${ }^{17}$

There is no trace now visible of scars left by the side-walls of the former chancel, but it is evident that the east wall of the building has been extensively refaced and patched. Moreover, slight changes in the plane of the wall suggest that it was not built as a single straight wall; the simultaneous construction of a chancel to the east would explain these minor deviations in the plane of the wall. ${ }^{18}$ The stone plinth along the south wall is continued as a rendered feature along the east wall, rising with ground level towards the north; it seems likely that in the east wall the plinth is a modern feature.

The battered remnant of the chancel-arch is thus the only early opening of which any trace has survived. The position of the original entrance door is unknown, but may well have been in the west wall; there is now a large fireplace and chimney in the west wall which has probably destroyed any trace of such a doorway.

It is the megalithic quoins of oolitic limestone which are the most distinctive feature of St Helen's. These have usually been described as consisting of longand-short work, ${ }^{19}$ though they do not display the regular alternation of tall pillar stones with flat stones bonding deeply into both adjacent walls. The quoining consists rather of massive oblong pillar stones bonding more deeply into alternating faces of the wall, coupled with occasional flat stones which bond deeply into one wall only in accordance with the alternating pattern of the oblong pillar stones. The south-east quoin is visible on both faces and serves well to illustrate the character of the quoining. The lowest stone is a massive

\footnotetext{
17 In the former listed building description quoted in $\mathrm{n.} 9$ above.

18 I am grateful to Richard Bryant for pointing this out to me during a site visit.

19 For instance in the Rснме description quoted in $n$. 11 above and in the listed building description in n. 14 .
} 
pillar stone $1.55 \mathrm{~m}$ in height, oblong in shape, extending further into the south face (up to $0.6 \mathrm{~m}$ ) than into the east face (up to $0.3 \mathrm{~m}$ ). Above this is another pillar stone $0.84 \mathrm{~m}$ in height, again oblong in shape, extending further into the east face (up to $0.6 \mathrm{~m}$ ) than into the south face (up to $0.24 \mathrm{~m}$ ). There is then a flat stone only $0.22 \mathrm{~m}$ in height, which extends more deeply into the south face than the east face, followed by a tall pillar stone which extends more deeply into the east face than into the south face; above that level the quoining belongs to the later increase in the height of the wall. Only one face is visible of the south-west and north-east quoins, but these seem to follow a similar pattern; the largest stone is the lowest in the south-west quoin, which is $1.70 \mathrm{~m}$ in height.

The stones used for the quoining display no obvious traces of reuse from Roman buildings such as lewis-holes, but it does seem likely that the massive stones used to form the quoins derive from a Roman building or buildings. The small Roman town at White Walls in the parish of Easton Grey a little under three miles to the west would be one possibility, and the small town at Nettleton Scrub (with a substantial temple) about nine miles to the south-west is another option. ${ }^{20}$ However, stonework of this size is more likely to derive from a major town with large-scale public engineering projects such as baths, bridges, temples, and defensive walls. Cirencester, just over ten miles to the north, seems the most likely source, with Bath 18 miles to the south-west another possibility. ${ }^{21}$ All of the sites listed lie on the Fosse Way. Detailed petrological examination of the quoins might well prove helpful in identifying the source of the stone.

An extremely unusual feature at the top of the north-east quoin is a carved kneeler (Fig. 21.5), that is to say a stone projecting over the wall below at the bottom of the coping on the gable end of a roof. ${ }^{22}$ The stone, which is also of oolitic limestone, measures $0.42 \mathrm{~m}$ in maximum width and $0.25 \mathrm{~m}$ in maximum height. The decoration consists of a spiral volute in shallow relief, from which a pair of broad mouldings rise parallel to the chamfered outer face of the kneeler. The two mouldings are divided by a narrow incised groove; the upper moulding tapers slightly as it rises. It is possible that something has been lost from the top of the stone which acted as a stop to the two mouldings. The presence of the kneeler implies a roof with a substantial overhang.

20 Mark Corney, "The Romano-British Nucleated Settlements of Wiltshire," in Roman Wiltshire and After: Papers in Honour of Ken Annable, ed. Peter Ellis (Devizes, 2001), pp. 5-38, at pp. $23^{-26,30-34 .}$

21 Although Bath is linked to Malmesbury by the River Avon, the river is not navigable for most of this stretch.

22 The RCHME description quoted in n. 11 above suggests that "this sculpture is clearly not in its original position," but the sculpture does not seem to have been recognized as a kneeler. 


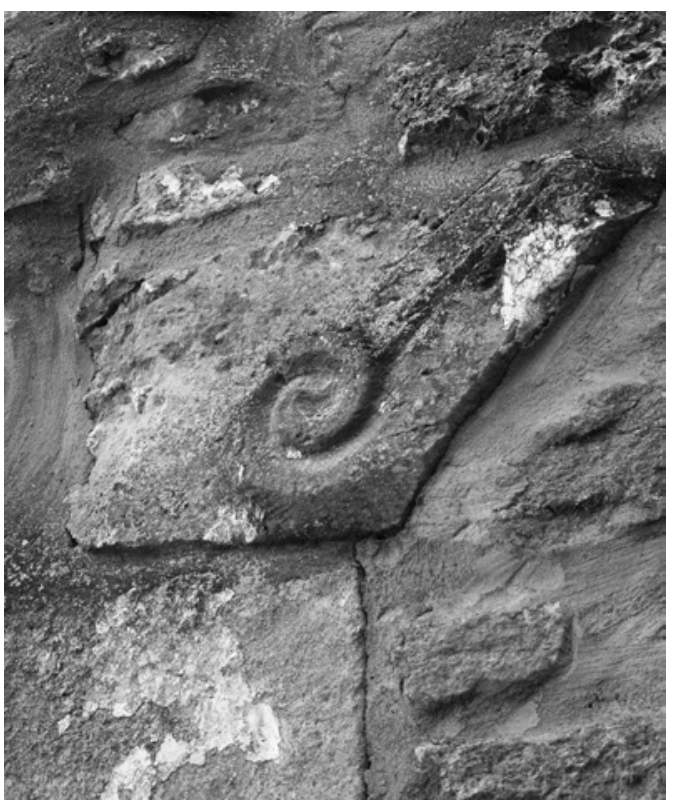

FIGURE 21.5 View of the kneeler at the top of the north-east quoin of the former chapel of St Helen at Malmesbury

(C) AUTHOR

At the top of the south face of the lowest stone of the south-east quoin, a much-weathered scratch-dial survives. This is the only feature visible in the present building likely to be of later medieval date.

\section{Documentary Evidence}

There is no surviving medieval documentation for St Helen's, assuming that there was not at some stage a change in dedication. The building first appears in 1575 in a grant of a large number of 'concealed lands' to John Herbert and Andrew Palmer; under this grant they received St Ellen's chapel together with lands which had pertained to it in Malmesbury, Foxley, and Burton Hill tithing in Malmesbury. ${ }^{23}$ 'Concealed lands' were properties which had escaped Crown ownership following the Dissolution of the Monasteries in the 153 os and of the

23 Calendar of the Patent Rolls Preserved in the Public Record Office, Elizabeth I, VI, 1572-75 (London, 1973), no. 2382 (pp. 408-14, at 408). The grant also included a chapel of All Hallows at Malmesbury with lands in Westport and Burton Hill; this chapel was located in the 
Chantries in 1547; much energy was expended (and much unpopularity incurred) by those licensed to search for them. ${ }^{24}$ We learn from this record that St Helen's had remained in some sort of ecclesiastical use until the 1530 s or 1540 s, but no further details are given.

According to Moffatt, St Helen's was in the possession of the borough when he wrote his history of the town, published in $1805 \cdot{ }^{25}$ More of the early modern and later history of the building could doubtless be gleaned from the borough archives.

\section{Date}

There is insufficient evidence to permit a close dating for the structure of St Helen's. The quoining is akin to long-and-short work, which would suggest a date in the 1oth or 11th centuries. ${ }^{26}$ It should not be regarded as certain that the building pre-dates the Conquest, for long-and-short quoining continued to be used after the Conquest, for instance in the Castle chapel of $c .1070$ at Winchester. ${ }^{27}$ The spiral ornament on the kneeler cannot be used to suggest any closer dating, for spirals are fairly common, but the most ready parallels for such ornament in an architectural context come from the late 1oth and 11th centuries. Similar spiral ornament, both in terms of scale and architectural context, may for instance be found on two mid-to late 11th-century capitals in the belfry windows at Sompting (West Sussex); on the side faces of each capital two heavy, rounded stems rise from a narrow roll moulding to end in tight scrolls or spirals. ${ }^{28} \mathrm{~A}$ late 1oth- or early 11th-century example of a carved roof

High Street according to Richard H. Luce, The History of the Abbey and Town of Malmesbury (Malmesbury, 1979), p. 38.

24 C.J. Kitching, "The Quest for Concealed Lands in the Reign of Elizabeth I," TRHS 5th ser. 24 (1974), 63-78.

25 Moffatt, History of the Town of Malmesbury, p. 115. Moffatt also states that St Helen's was confirmed to the borough by William III in his charter of 1696; however, St Helen's is not mentioned by name in the printed text, though it may well be subsumed in the "Burgess Lands" to which the charter refers: Authenticated Copy of Charter Granted to the Free Men of Malmesbury by King Athelstan and Ratified by King William III (Malmesbury, 1910), esp. pp. 21-22.

26 H.M. Taylor and Joan Taylor, Anglo-Saxon Architecture, 3 vols (Cambridge, 1965-78), 3:939-57.

27 Martin Biddle, "Excavations at Winchester, 1971: Tenth and Final Interim Report: Part I," AntJ 55 (1975), 96-126, at pp. 106-09.

28 Dominic Tweddle, Martin Biddle, and Birthe Kjølbye-Biddle, Corpus of Anglo-Saxon Stone Sculpture, IV, South-East England (Oxford, 1995), pp. 183-84, ills. 205-12. 
finial with a tight, spiral terminal can be found at Bibury (Gloucs.) on a highlevel wall panel that depicts a steeply-roofed, two-cell fictive building. ${ }^{29}$

\section{Discussion}

Two features of St Helen's are of particular interest. First there is the surviving decorated kneeler, a feature otherwise unparalleled in pre-Conquest churches. Secondly there is the evidence for an extremely narrow chancel-arch, no larger than a doorway and thus comparable to the very small chancel-arch at Bradford-on-Avon, only about 18 miles to the south; at Bradford the chancel-arch is $1.07 \mathrm{~m}$ in width and $2.97 \mathrm{~m}$ in height..$^{30}$ An excavated example of a church with a very narrow doorway-like opening between nave and chancel is provided by the church of St Mary, Tanner Street, Winchester; an earlier rectangular building was converted into the nave, with an apsidal chancel built to its east. A very narrow chancel-arch about $1 \mathrm{~m}$ in width opened between the two compartments; this arrangement seems to belong to the early 1oth century, and the arrangement had been given up by the later 11th century. ${ }^{31} \mathrm{~A}$ further example is perhaps provided by the building known as Prior's Hall at Widdington (Essex). ${ }^{32}$ The building is now a house (formerly known as Stone Hall), and may have originated as such, but seems more likely to have been a church which went out of use at a very early date and was adapted to use as a secular building. What survives is a 'nave' aligned east-west about $12 \mathrm{~m}$ in length with long-and-short quoins at the angles. There is evidence that there was a narrower structure to the east, presumably a chancel. In the middle of the east wall of the nave there is a narrow doorway-like opening; the opening is roundheaded, has imposts of square section and measures only $1.00 \mathrm{~m}$ in width.

It seems unlikely that very narrow chancel-arches would survive in any church which remained in normal use during the liturgical changes of the later 11th, 12th, and 13th centuries. In particular the movement of altars to the east

29 Richard Bryant, Corpus of Anglo-Saxon Stone Sculpture, x, The Western Midlands (Oxford, 2012), pp. 139-40, ill. 42.

30 Taylor and Taylor, Anglo-Saxon Architecture, 1:86-89; H.M. Taylor, "The Anglo-Saxon Chapel at Bradford-on-Avon," Archaeological Journal 130 (1973), 141-71.

31 Martin Biddle, "Excavations at Winchester, 1970: Ninth Interim Report," AntJ 52 (1972), 93-131, at pp. 104-07; "Excavations at Winchester, 1971: Tenth and Final Interim Report: Part II," AntJ 55 (1975), 295-337, at pp. 312-13. For the dating, see the final phasing in Martin Biddle, Object and Economy in Medieval Winchester, Winchester Studies 7.2, 2 vols (Oxford, 1990), 2:1166- 77 .

For a preliminary account of Prior's Hall, see Nicola Smith, "England's Oldest House?" Country Life 183 (31 August 1989), 84-85. 
end of chancels and the introduction of the Elevation of the Host would make the replacement of narrow chancel-arches with wider openings essential. ${ }^{33}$ It is unlikely to be coincidence that our three standing examples of narrow chancel-arches are all preserved in buildings which had unusual after-lives and finished up as domestic buildings in the case of Malmesbury and Widdington and as a school and cottage in the case of Bradford-on-Avon. We do not know when Bradford-on-Avon and Widdington went out of use as churches, though the absence of any ecclesiastical features of 12th- to 15th-century date may suggest in both cases that this took place not long after the Norman Conquest (or even before it). In the case of Malmesbury the chapel apparently continued in use until the Reformation, but it may well be that the chancel was removed at an early date. At Winchester, the example of St Mary, Tanner Street makes the point that in churches which remained in congregational use, a narrow chancel-arch is likely to have been replaced by alternative arrangements.

It remains to discuss the purpose for which St Helen's was originally founded, together with its possible uses until the time of the Reformation. Malmesbury's ecclesiastical history in the pre-Conquest period is dominated by the abbey founded in the $7^{\text {th }}$ century. It is unfortunate that the records of the abbey and the writings of its premier historian, William of Malmesbury, shed no light on the origins and evolution of St Helen's. Indeed the history of the several preConquest churches within the abbey precinct is problematic; ${ }^{34}$ archaeology has so far produced only a bone mount datable between the late 9 th and mid-1oth centuries, found during excavations in part of the cemetery. ${ }^{35}$

It is unknown when the suburb of Westport was first laid out, and it is also unclear who promoted this extension to the town; the king and the abbot of Malmesbury are the most likely candidates. Westport is not separately listed in Domesday Book of 1086 and is first mentioned by name in $1135 .{ }^{36} \mathrm{Jeremy} \mathrm{Haslam}$ has plausibly argued that the Westport suburb was established in the late Anglo-Saxon period. ${ }^{37}$ The discovery of St Helen's lends additional support to his argument. A parochial function for St Helen's seems excluded, for there were two parish churches, St Paul serving the town within the walls, and St Mary,

33 For these liturgical changes, see P.S. Barnwell, "The Laity, the Clergy and the Divine Presence: The Use of Space in Smaller Churches of the Eleventh and Twelfth Centuries," Journal of the British Archaeological Association 157 (2004), 41-60.

34 On the evidence for churches within the precinct, see Appendix B, "The Churches of Malmesbury Abbey," in WM, GP, 2:330-33. Malmesbury Abbey: Excavations at the Old Cinema Site, Market Cross," WANHM 104 (2011), 166-92, at pp. 185-86, 188.

37 Haslam, "The Towns of Wiltshire," pp. 116-17. 
Westport serving the western suburb. Both had substantial parishes extending into the surrounding countryside and they probably once formed a single unit. ${ }^{38}$

However, other possibilities exist for the original function of St Helen's. It might have originated as the private chapel of a wealthy landowner with interests in the Westport suburb, perhaps with a personal devotion to St Helena. Barbara Yorke has hinted at the possibility of an association with the Westport market. ${ }^{39}$ It might also be proposed that St Helen's was established by Malmesbury Abbey as a stational church in a processional liturgy. As Helen Gittos has recently shown, the liturgical sources reveal "that processions between churches were integral to the celebration of many major feasts, certainly in the latetenth and eleventh centuries and probably from the late-seventh century."40 For instance the Palm Sunday procession at Canterbury in the late AngloSaxon period involved a visit to the extra-mural church of St Martin, and similarly at Winchester in the early Norman period the procession took in the extra-mural church of St James. ${ }^{41}$ At Malmesbury a procession crossing the high and narrow neck of land between St Helen's and the abbey would have formed an impressive and dramatic spectacle.

A few tentative additional thoughts in support of this suggestion can be put forward. A dedication to St Helena may have been regarded as particularly appropriate for an extra-mural church in Westport, based on Roman precedent. In his Gesta regum Anglorum, written in the mid-1120s, William of Malmesbury included a Roman itinerarium apparently composed between 648 and 682; this itinerarium lists the gates and roads leading out of Rome in turn, with details of the saints (mainly martyrs), to which they led. It has plausibly been suggested that William's itinerarium derives from a copy obtained by Aldhelm at the time of his visit to Rome, probably in $688-89 ;{ }^{42}$ if so, it would have been available for consultation by the community of Malmesbury throughout the Anglo-Saxon period. Of particular interest to us is this text's reference to the seventh gate: "Septima porta modo Maior dicitur, olim Sircurana dicebatur, et Via Lauicana

38 The parish boundaries are mapped in Haslam, "The Towns of Wiltshire," p. 113, Fig. 46, and in $v c H$ Wilts 14, pp. 4, 26, 128, 230.

39 Yorke, Wessex, pp. 232, 234. More generally on the links between churches and marketplaces, see Richard Morris, Churches in the Landscape (London, 1989), pp. 212-13.

40 For discussion of processional liturgy involving stations at different churches, see Helen Gittos, Liturgy, Architecture, and Sacred Places in Anglo-Saxon England (Oxford, 2013), pp. 103-45 (with the quotation at p. 110).

41 Gittos, Liturgy, Architecture, and Sacred Places, pp. 124-34.

42 For the text, see WM, GRA, IV.352, I: pp. 614-20. For the suggestion that the text had been preserved at Malmesbury since Aldhelm's visit, see Lapidge, "The Career of Aldhelm," pp. $5^{2-64}$. 
quae ad beatam Helenam tendit" - "The seventh gate is now called the Greater gate, but was formerly the Sircuran [=Sessorian], and there is the Via Labicana, which leads to St Helena." ${ }^{43}$ At Malmesbury the gate leading to the suburb of Westport (the town's only early suburb) stood immediately to the west of the precinct, about $50 \mathrm{~m}$ west of the facade of the Norman abbey church (Fig. 21.1). ${ }^{44}$ This was in all likelihood the gate through which ceremonial entrances to the abbey were made in the 1oth and 11th centuries, and it may well have been regarded by the community as their equivalent of the 'greater gate'.

Moreover, the role attributed to St Helena, the mother of the Roman emperor Constantine, in the discovery of the True Cross, may also have been important. In the Gesta regum Anglorum, William of Malmesbury listed the gifts made by Hugh, duke of the Franks, when he sent an embassy in 926 to King Æthelstan (924-39) to ask for the hand of his sister. According to William, these gifts included the sword of Constantine, Charlemagne's lance, the banner of St Maurice, and:

a small piece of the holy and wonderful Cross enclosed in crystal, which the eye can penetrate, solid rock though it is, and discern the wood, its colour and its size; a small portion too, mounted in the same fashion, of the crown of thorns. ${ }^{45}$

In the Gesta pontificum Anglorum (also written in the 1120s), William relates that Æthelstan had:

lavished on the monastery many estates, many palls, a gold cross, phylacteries, also of gold, and a fragment of the Lord's cross which he had been sent by Hugh king of the Franks. ${ }^{46}$

Sarah Foot has shown that the claim to a fragment of the True Cross should be treated with caution, as the abbey of Milton also claimed that it had received from Æthelstan the gift of a fragment of the True Cross; in addition Exeter Cathedral claimed to have possession of one-third of all Æthelstan's relic collection, and its 11th-century Old English list of relics included a piece of the

43 WM, GRA, IV. 352 , I: p. 618 . The 'Sircuran gate' of the text is evidently a corruption of the original text, which must have referred to the Sessorian gate; WM, GRA vol. 2, p. 309. A map showing the full line of the medieval town defences with the position of the west gate was published by Longman, "Iron Age and Later Defences," p. 107, Fig. 2.

45 WM, GRA, II.135, I: pp. 218-20.

46 WM, $G P$, v.246, 1:592. 
True Cross. ${ }^{47}$ Nevertheless we need not doubt that in William's own day, the abbey of Malmesbury had a relic of the cross set in crystal, probably embedded in a processional cross like the Ardennes Cross of the second quarter of the gth century or the Theophanu cross from Essen of the middle of the 11th century; in these examples the cross fragments were placed behind a crystal set at the central crossing. ${ }^{48}$ It is not difficult to imagine a spectacular cross of this type forming a prominent feature of processions from St Helen's. However, it should be stressed that the line of thought put forward here is highly speculative.

As to the use of St Helen's in the later medieval period, no evidence can currently be brought to bear, and we must simply recognize that many categories of minor churches, for instance churches serving hermitages and hospitals and those acting as chantries, are under-represented in our surviving sources. The function of St Helen's chapel throughout its history down to the 16th century thus remains unknown.

\section{Conclusion}

The church of St Helen's is a useful addition to the corpus of buildings constructed in pre-Conquest style, and it deserves to be better known. It is to be hoped that further evidence will come to light to provide more information about its original purpose and its subsequent survival through to the 16th century.9

47 Æthelstan's relic collection and his donations of relics are discussed by Sarah Foot, Ethelstan: The First King of England (New Haven, CT, 2011), pp. 188-203.

48 For the Ardennes Cross (in the Germanisches Nationalmuseum, Nuremberg), see 799Kunst und Kultur der Karolingerzeit. Karl der Grosse und Papst Leo III. in Paderborn, ed. Christoph Stiegemann and Matthias Wemhoff, 3 vols (Mainz, 1999), 2:797-80o, cat. no. XI.12; for the cross of Theophanu (in the Domschatzkammer in Essen), see Ulrich Knapp and Klaus Gereon Beuckers, Farbiges Gold. Die ottonischen Kreuze in der Domschatzkammer Essen und ihre Emails (Essen, 2006), pp. 11-12. There are several other examples of crosses of similar type from the 1oth-12th centuries.

49 Whenever I have visited St Helen's, Kes and Mary Smith have been genial hosts and they have welcomed a variety of friends and colleagues whom I have taken to see St Helen's. Richard Bryant, Carolyn Heighway, Graham Jones, Malcolm Thurlby and Nicola Smith have all visited the building with me and all have made useful comments and observations, as did the anonymous referee. Richard Bryant has also provided me with much help with the illustrations. Jeremy Haslam kindly allowed me to adapt one of his maps of Malmesbury. 